\title{
Otomatik Çeviri Araçlarının Yabancı Dil Öğretiminde Kullanımı: Google Çeviri Örneği ${ }^{*}$
}

\author{
Dr. Öğr. Üyesi Erdinç Aslan \\ Marmara Üniversitesi Fen-Edebiyat Fakültesi \\ Fransizca Mütercim Tercümanlık Bölümü \\ erdincaslan36@hotmail.com
}

Öz

Makine veya bilgisayarlı çeviri olarak da adlandırılan otomatik çeviri, insan müdahalesi olmadan bilgisayarlarla ve mobil cihazlarla metinlerin bir dilden başka dile otomatik olarak çevirisinin yapılmasıdır. Son elli yılda teknoloji alanında yaşanan gelişmeler, özellikle batı dilleri arasında daha iyi çeviri yapabilen araçlar geliştirilmesine olanak sağlamıştır. Birkaç yıldan beri ise Türkçe, Korece, Çince gibi yapısal olarak farklı diller arasında da daha iyi çeviriler yapan uygulamalar geliştirildiğini görmekteyiz. Bununla birlikte bu araçların sunduğu imkânlar çeviri yapma ile sınırlı değildir. Bu araçlardan yabancı dil öğretiminde konuşma, dinleme, okuma ve yazma etkinliklerinde yararlanılabilir. Fakat otomatik çeviri araçlarının sunduğu bu olanakların öğrenciler tarafından ne kadar etkili ve verimli kullanıldıkları yeteri kadar bilinmemektedir. Bu çalışmada, öğrencilerin yabancı dil öğrenirken bu araçlardan yararlanıp yararlanmadıkları, yararlanıyorlarsa nasıl yararlandıkları, hangi etkinliklerde bu araçları kullandıkları, bu konudaki eksiklik ve sınırlılıkların neler olduğu tespit edilmeye çalışılmaktadır. Ayrıca bu araçlarla örnek etkinlikler yapılarak mevcut durum ortaya konulmaya çalışılmakta ve böylelikle buradan elde edilen bilgilerle bu araçların yardımcı birer ders materyali olarak etkin ve verimli kullanılmasının yolları aranmaktadır. Bu amaçla dört tane örnek etkinlik hazırlanmış ve bunlar 2017-2018 sonbahar döneminde Marmara Üniversitesi Fransizca Mütercim Tercümanlık bölümü İngilizce dersinde gerçekleştirilmiştir. Ayrıca alan yazın taranarak ve uzman görüşü alınarak bir anket hazırlanmış ve etkinlik sonrasında uygulanmıştır. Elde edilen verilerin analizinde Betimsel İstatistik Tekniği kullanılmış, soruların analizinde ise İçerik Analizinden yararlanılmıştır.

Anahtar Kelimeler: Otomatik çeviri, yabancı dil öğretimi, ders materyali, makine çevirisi.

\footnotetext{
* Bu makale, 21-22 Aralık 2017 tarihinde Yıldız Teknik Üniversitesi tarafından düzenlenen IV. Yıldız Sosyal Bilimler Kongresi'nde sunulan bildirinin genişletilmiş şeklidir. 


\title{
Use of Automatic Translation Tools in Foreign Language Teaching: Example of Google Translate
}

\begin{abstract}
Automatic translation, also called machine translation is the automatic translation of texts from one language to another, with computers and mobile devices without human intervention. In the last fifty years, developments in the field of technology have enabled the development of tools for better translation, especially in the western languages. However, the facilities provided by these tools are not limited to translation. These tools can be used in speaking, listening, reading and writing activities in foreign language teaching. In this study, it is tried to be determined how efficiently students use them, what are the shortcomings and limitations. Also the current situation is tried to be revealed by making sample activities with these tools and so that it is sought to find ways of using these tools effectively and efficiently as teaching materials. Four sample events were prepared for this purpose and they were realized in the English course of French Translation and Interpretation Department of Marmara University in autumn 2017-2018. In addition, a questionnaire was prepared and administered after the exercices. Descriptive Statistical Technique was used in the analysis of the obtained data and Content Analysis was used in the analysis of open ended questions.
\end{abstract}

Keywords: Automatic translation, foreign language teaching, course material, machine translation. 


\section{GİRIŞ}

Makine veya bilgisayarlı çeviri olarak da adlandırılan otomatik çeviri, insan müdahalesi olmadan bilgisayarlarla ve mobil cihazlarla metinlerin bir dilden başka dile otomatik olarak çevirisinin yapılmasıdır. Son elli yılda teknoloji alanında yaşanan gelişmeler, özellikle batı dilleri arasında daha iyi çeviri yapabilen araçlar geliştirilmesine olanak sağlamıştır. Son birkaç yılda yapılan çalışmalarda ise Türkçe, Korece, Çince gibi yapısal olarak farklı diller arasında da daha iyi çeviriler yapan uygulamalar geliştirildiğini görmekteyiz. Fakat buna rağmen makine çevirisi ile yüksek kalitede çeviri yapmak henüz olanaklı değildir. Bunun en önemli nedeni bu yazılımların dilin inceliklerini tam olarak yansitamamalarıdır.

Bununla birlikte bu araçların sunduğu imkânlar çeviri yapma ile sınırlı değildir. Birer sözlük işlevi de gören bu araçlardan yabancı dil öğretiminde konuşma, dinleme, okuma ve yazma etkinliklerinde yararlanılabilir. Örneğin sözcükler hem yazılı hem de sözlü olarak sisteme girilebildiğinden öğrenci, bir yandan sözcüğün anlamını ve cümle içerisinde kullanımını öğrenirken bir yandan da hem sözcüklerin telaffuzunu dinleyebilir hem de kendi telaffuzunu değerlendirerek varsa yanlışlarını düzeltebilir. Bunun yanı sıra deyimler, atasözleri, kalıp sözler gibi söz varlıklarının öğretilmesinde otomatik çeviri araçlarından yararlanılabilir. Ayrıca diller arasındaki yapısal benzerlik ve farklılıkların öğretilmesinde de bu araçlara başvurulabilir. Mobil uygulamaları sayesinde yer ve zaman sınırlaması olmadan bu olanaklara ulaşma imkânı sunması ise bu araçların en önemli özelliklerindendir.

Fakat otomatik çeviri araçlarının sunduğu bu olanakların öğrenciler tarafından kullanılıp kullanılmadıkları, kullanılıyorsa ne kadar etkili ve verimli kullanıldıkları yeteri kadar bilinmemektedir. Biz de çalışmamızda öğrencilerin yabancı dil öğrenirken bu araçlardan yararlanıp yararlanmadıklarını, yararlanıyorlarsa nasıl yararlandıklarını, hangi etkinliklerde bu araçları kullandıklarını, bu konudaki eksiklik ve sinırlılıkların neler olduğunu tespit etmeyi ve buradan elde edilen bilgilerle bu araçların yardımcı birer ders materyali olarak etkin ve verimli kullanılmasının yollarını aramaya çalıştık.

\section{OTOMATIK ÇEVİRININN GEÇMIŞİ VE GOOGLE ÇEVİRI}

Otomatik çeviri veya makine çevirisi fikrinin geçmişi 17. yüzyılda yaşamış Fransız filolog ve matematikçi Rene Descartes'in diller arasında çeviri yapacak sözlük önerisine dayansa da (Yaguella 1944) bu alanda ilk çalışmaların ikinci dünya savaşından önce ve sonra ortaya çıktığını görmekteyiz. 1933'te birbirinden müstakil şekilde hem Fransa'da hem de Rusya'da kâğıt şerit yoluyla iki farklı tercüme mekanizması için patent verilmesi makine çevirisi çalışmalarının öncüsü olarak kabul edilebilir (Novak 2015). İkinci dünya savaşı yıllarında taraflar birbirlerine ait gizli bilgileri elde etmek için çeşitli kripto çözme makineleri geliştirdiler. Alman yapımı bir elektromanyetik şifre çözme makinası olan Enigma, bunlardan biridir. Çalışma prensibi oldukça karışık olan bu makine; mesajları, rotor ve elektrik akımları yardımıyla milyonlarca farklı şekle dönüştürebilme kabiliyetine sahipti. Bu makineler savaş sonrasında da bilim insanlarını bilgisayar vasıtasıyla çeviri imkânlarını araştırmaya yöneltti.

İkinci dünya savaşından sonra otomatik çeviri alanındaki çalışmalar hız kazandı. 1949 yılında Alman şifreleme makinelerince üretilen askeri kodları çözmek için geliştirilen İngilizlerin Colossus bilgisayarlarından etkilenen Amerikan Rockefeller Enstitüsü'nden Warren Weaver, bir çeviri modeli önerisinde bulunmuş ve bir rapor hazırlamıştı. Bu rapor özellikle askeri çevrelerde ilgi uyandırmış ve otomatik çeviri araçlarının geliştirilmesi için 
destek almayı başarmıştı. Weaver raporuna şöyle bir not da eklemişti: “Önümde Rusça yazılı bir metin var, ama aslında İngilizce yazılmış ve bazı garip sembollerle kodlanmış gibi davranacağım. Tüm yapmam gereken metinde yer alan bilgiyi ele geçirmek için koddan kurtulmaktır" (Yet 2016). 1954'te ise Georgetown Üniversitesi ve IBM ortaklığında ilk makine çevirisini gerçekleştirildi. 60'dan fazla Rusça cümleyi İngilizceye çevirmeyi başaran araştırmacılar üç beş yıl içinde makine çevirisinin bir sorun olmaktan çıkacağını dile getiriyorlard1 (Chéragui 2012: 161). Fakat beklenen olmad1 ve on yıl boyunca bu alanda hiçbir ciddi ilerleme sağlanamadı. 1966'da ise ALPAC (Automatic Language Processing Advisory Committee) Raporu makine çevirisi ile ilgili olumsuz bir tablo çizdi ve bu alana yapılan yatırımların durdurulmasına neden oldu. Bu rapordan hareketle Birleşik Devletleri'nde makine çevirisi ile ilgili bütün projeler askıya alındı (Gil-Pym 2006).

$\mathrm{Bu}$ olumsuz tabloya rağmen 1970'li yıllar boyunca makine çevirisi alanındaki çalışmalar devam etti. Systran projesi Avrupa Birliğin tarafından satın alındıve uygulamaya konuldu. Bununla birlikte yine Avrupa'da Globalink ve Eurotran gibi projeler de devam etti. Fakat istenilen başarı bir türlü elde edilemedi. Sonunda saygın bir bilim insanı olan Janet Pak'ın, makine çevirisini olanaksız kılan 30 sayfalık bir rapor yayınlaması bütün bu yatırımlara son noktayı koydu. Amerika ve Kanada gibi ülkeler başta olmak üzere yatırımcılar çalışmalarını bu rapor doğrultusunda tamamen rafa kaldırdılar (Mihrabi 2006).

1990'lı yıllara geldiğimizde İnternet'in hayatımıza girmesiyle birlikte makine çevirisi anlayışında da değişiklikler oldu. Bilgisayarların hızlanması ve Internet datasının artması ile formüle dayanan bu motorun istatistik ile desteklenebileceği öngörüldü. Bunun yanı sıra yapay zekâ kullanılarak yapılan çevirilerin insan eliyle düzeltilip çevirinin iyileştirilmesi sağlanmaya çalışıldı. Google, motor + istatistik + yapay zekâ yapısını bir adım daha geliştirerek Nöral Çeviri dedikleri bir yapı ile makine çevirisini farklı bir boyuta taşıdı. Bu sistem ile bir cümleye iki farklı sistem etki ediyor. Birincisi eldeki çok büyük sözlük ile cümleyi karşılaştırarak cümlenin ne anlama geldiğini tanımlıyor, diğeri de çeviriyi yapıyor. Böylece çeviri istatistiksel ve anlama bağlı olarak doğruya daha yakın yapılmış oluyor (Calli 2016).

Günümüzde bu alan en çok yatırım yapan şirketlerden biri hiç kuşkusuz Google'dur. Şirket, Nisan 2016'da İngilizce ve Arapça dilleri arasında çeviri yaparak hizmet vermeye başladı. Şubat 2009'dan itibaren Türkçeyi de çeviri dillerine dahil eden Google, 2016 Aralık ayında hizmete sunduğu Nöral çeviri sistemine Türkçeyi de dahil etti. Günümüzde 100'den farklı dilde ücretsiz çeviri hizmeti sağlayan Google yazılımı; sözcükleri, cümleleri ve web sayfaları desteklenen dillerin tüm kombinasyonlarını çevirebilir. Ayrıca gerçek zamanlı sözlü çeviri alanında da önemli gelişmeler elde etmiş ve gelecekte bu yöndeki çalışmalar için büyük umutlar vaat etmiştir.

\section{TEKNOLOJI VE YABANCI DİL ÖĞRETIMİ}

Teknolojide yaşanan gelişmeler birçok alanda yeni olanaklar ortaya çıkardığı gibi ders araç gereçleriyle ilgili de yeni olanaklar sunmaktadır. Bugün artık dil öğrenmeye yönelik etkinliklerin sınıf ortamında bir bütünlük içerisinde gerçekleştirilmesi için öğretmen ve kitabın yeterli olmayacağı teknolojinin sunduğu olanaklardan da yararlanmak gerektiği dilbilimciler tarafından kabul edilmektedir. Kuşçu'ya (2017: 25) göre "yetkin bir düzeyde yabancı dil öğrenmenin en doğru yolu, o dilin anadil olarak konuşulduğu yerde yaşamak ve o dilde eğitim görmekten geçer. Bu şartlar sağlanamadığında, yabancı dil öğrenebilmek ya da öğretebilmek için değişik yaklaşımlara, yöntemlere, tekniklere ve araç-gereçlere 
başvurmak gerekir." Nitekim dil öğretmek amacıyla hazırlanmış birçok program ve uygulama bu alanın hizmetine sunulmuştur. Bunun yanı sıra başka amaçlar için hazırlanmış fakat eğitsel değeri bulunan birçok araç gerek ise uygun yöntem ve tekniklerle dil öğretim etkinliklerinde kullanılabilmekte ve dil öğretiminin geliştirmeyi hedeflediği temel yetiler üst düzeyde geliştirilebilmektedir.

Ses, yazı, görüntü gibi unsurların bir arada kullanıldığı yeni teknolojiler, üst düzeyde etkileşim ortamı sunmakta ve birden fazla duyu organına hitap ederek etkili öğrenmeler gerçekleştirilmesine olanak sağlamaktadır. Nitekim Yalın (2010: 20), bu konuya dikkat çekerek, "öğrenme işlemine katılan duyu organlarımızın sayısı ne kadar fazla ise o kadar iyi öğrenir ve o kadar geç unuturuz" demektedir. Bu bakımdan diyebiliriz ki yeni teknolojilerin sunduğu olanaklardan yararlanarak yabancı dil eğitiminde, genelde bireye kazandırılması amaçlanan; duyduğunu anlama, okuduğunu anlama, konuşma ve yazma becerileri geliştirilebilmektedir.

Aktaş (2005: 52) ise, bu araçlar yardımıyla öğrencinin, dilin iletişimde kullanım ortamlarını tanıdığını, dinleme ve anlama becerisinin ediniminde gerekli olan doğru vurgulamayı, tonlamayı ve iletişime eşlik eden el, yüz, beden hareketlerini de tanıdığını belirtmektedir. Ayrıca öğrencinin diğer becerilerinin yanında konuşma becerisinin gelişmesini de etkilediğin, öğrencinin günlük konuşma ortamına ve hızına, tümce yapılarına alışabildiğini ve ayrıca sözcük dağarcığını da zenginleştirebildiğini ifade etmektedir.

Yeni teknolojilerin bir diğer önemli avantajlarından biri de bireysel öğrenmeye olanak sağlamasıdır. Öğretmen yeni uygulamalarla her öğrencinin düzeyini ve öğrenme özelliklerini dikkate alarak etkinlikler hazırlayabilir ve böylece öğrencilerin bireysel öğrenme gereksinimlerini karşılayarak onlara öğrendikleri yabancı dili kullanma fırsatı verebilecektir. Ayrıca bu araçlar uygun yöntem ve tekniklerle verimli bir şekilde kullanılarak dersler klasik ezberci yöntemden kurtulacak, öğrencilerin derslere olan ilgili artacak ve böylece etkileşimli bir sınıf ortamı oluşturularak öğrenme yaşantıları zenginleştirilecektir. Kısacası geleneksel yöntemler karşısında önemli üstünlükleri olmasından dolayı yabancı dil öğretiminde yeni teknolojilerin kullanılması zorunlu hale gelmektedir. Bütün bunlarla birlikte şunu da unutmamak gerekir ki Günday'ın (2015: 209) da dediği gibi "öğretmenin bu materyalleri hangi süreçlerde ne kadar ne nasıl entegre bir şekilde kullanacağı konularında formasyon sahibi olması bu başarıya ulaşmada önemli görülmektedir."

\section{OTOMATIK ÇEVİRI ARAÇLARININ ETKINLIKKLERDE KULLANIMI}

Otomatik çeviri araçlarından yabancı dil öğretiminin hedeflediği okuma, yazma, dinleme ve konuşma becerilerinin geliştirilmesinde uygulanacak etkinliklerde yararlanılabileceğini yukarıda belirtmiştik. Bu bölümde dört dil becerisinin geliştirilmesine yönelik örnek etkinlikler sunulmaktadır.

\section{Yazma Etkinliği}

Yazma becerisinin geliştirilmesine yönelik gerçekleştirilen etkinlik Döngüsel Yazma Etkinliğidir. Bu etkinlikte Takıl'ın (2016: 302) dediği gibi, “öğrencinin yazdığı metinlerin öğretmence incelenmesi ve ardından sınıf ortamında öğrenciler tarafından düzeltilmesi ve tekrar öğretmenin kontrolünden geçmesi sebebiyle ortaya bir döngü çıkmaktadır. Bu sebeple etkinliğe döngüsel yazma adı verilmiştir." Biz de bu etkinliği ait bir plan örneği görmektesiniz.

SEFAD, 2018 (39): 87-104 


\begin{tabular}{|c|c|}
\hline Seviye & B2 \\
\hline Süre & 40 dakika \\
\hline Temel beceriler & Okuma, Yazma \\
\hline Etkinlik türleri & Döngüsel yazma tekniği \\
\hline Amaç & $\begin{array}{l}\text { Öğrencilerin okudukları metni anlamaları ve metindeki hataları tespit } \\
\text { ederek düzeltmeleri sağlanır. }\end{array}$ \\
\hline Materyaller & Otomatik çeviri aracı (Google Çeviri Sitesi), bilgisayar, tablet \\
\hline Süreç & $\begin{array}{l}\text { Öğretmen tarafından metin Google Çeviri'ye girilerek çevrilmesi } \\
\text { sağlanır. Öğrenciler, çeviri metnindeki yanlışları tespit ederek } \\
\text { düzeltmeye çalışır veya alternatif sözcük ve çeviri önerileri sunar. } \\
\text { Öğretmen, tespit edilen yanlışları veya önerileri tahtaya yazılmasını } \\
\text { veya yansı ekranından düzeltilmesini ister. Öğrenciler, kendi tespit ve } \\
\text { önerilerini yazar. Öğretmen bu süreç boyunca öğrencilere rehberlik eder } \\
\text { ve gerekli ipuçlarını vererek ve hatırlatmalar yaparak doğru metnin } \\
\text { yazılmasını sağlar. }\end{array}$ \\
\hline Metin & $\begin{array}{l}\text { Yazarlar "geri ülkelerden” söz ediyorlardı; bu da kuşkusuz o ülkelerin } \\
\text { insanlarını öfkelendiriyordu. Birleşmiş milletler, suçlamalardan } \\
\text { kaçınmak için, bazen gelişen ülke deyimini kullanır. Bugün, çoğu kişi az } \\
\text { gelişmiş ülke deyimini kabul etmektedir. Bu terimle ne anlatılmaktadır? } \\
\text { Verilen değişik tanımların çoğu aşağıdaki unsurları kapsar. } \\
\text { “Az gelişmiş bir ülke, kişi başına gerçek geliri, Kanada, Amerika } \\
\text { Birleşik Devletleri, İngiltere ve genellikle Batı Avrupa ülkelerinin } \\
\text { bugünkü kişi başına gelirlerine kıyasla düşük olan ülkedir. İyimser bir } \\
\text { görüşle, az gelişmiş bir ülke gelir düzeyinde önemli yükseltmeler } \\
\text { yapabilecek güçte bir ülke olarak düşünülür.” } \\
\text { Gelişmiş ve az gelişmiş ekonomiler arasındaki farkları ortaya koymak } \\
\text { için, az gelişmiş bir ülkede, örneğin, Hindistan, Haiti ya da Nijerya'da } \\
\text { yirmi bir yaşında tipik bir vatandaş olduğunuzu düşünün. } \\
\text { Yoksulsunuz. Üretip tükettiğiniz mallar için önemli bir karşılık } \\
\text { ayırsanız bile, kişi başına yıllık geliriniz ortalama olarak ancak } 100 \\
\text { dolardır; Kuzey Amerika'da ise } 3500 \text { dolardır. İnsan ırkının yalnızca } \\
\text { sekizde birinin yıllık gelirinin } 1200 \text { dolardan fazla olduğunu düşünmek }\end{array}$ \\
\hline
\end{tabular}




\begin{tabular}{|l|l|}
\hline & $\begin{array}{l}\text { sizi belki rahatlatabilir. Okuyan bir vatandaşınıza karşılık sizin gibi } \\
\text { okuma yazma bilmeyen üç vatandaşınız vardır. Ömrünüzün } \\
\text { uzunluğuna ilişkin bekleyişler, ileri ülkedeki ortalama bir kişininkinin } \\
\text { yalnızca üçte ikisi kadardır. Şimdiye kadar iki ya da üç kardeşiniz } \\
\text { erişkinlik dönemine kadar yaşamıştır; geçinmek için onlarla birlikte } \\
\text { çabalamak zorundasınız (Tecer 1980: 17). }\end{array}$ \\
\hline Değerlendirme & $\begin{array}{l}\text { Öğrencilerin cevapları kontrol edilir. Yanlışları sınıf ortamında } \\
\text { düzeltilir. }\end{array}$ \\
\hline
\end{tabular}

Aşağıda Google Çeviri ekranında bu etkinlikte kullanılan metni görmektesiniz. Google

ii

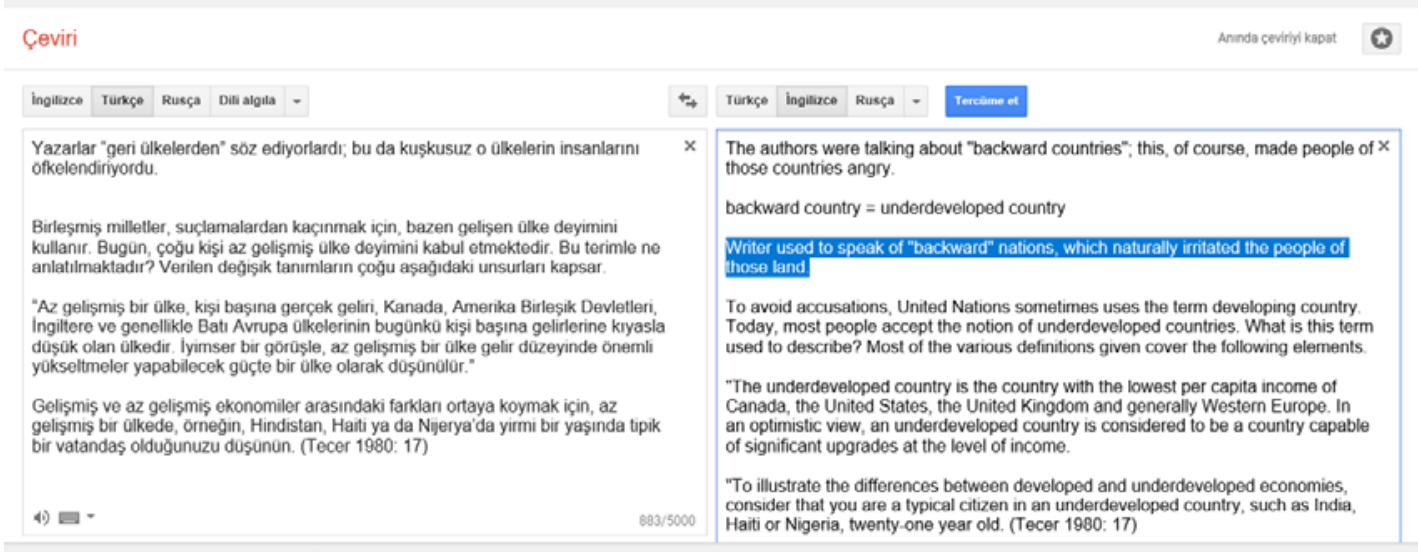

Resim 1. Yazma etkinliği metin örneği

$\mathrm{Bu}$ etkinlikte kullanılacak metnin önceden öğretmen tarafından otomatik çeviri aracına girilerek çevirisinin gözden geçirilmesi gerekmektedir. Zira metindeki hataların neler olduğu, öğrenci seviyesine uygun olup olmadığı, zorluk derecesi gibi unsurların önceden bilinmesi hem dersin planlanması hem de beklenmedik durumların ortaya çıkmasının engellenmesi adına önem arz etmektedir. Etkinlik esnasında öğretmen öğrencilerin hatalarla ilgili hem bireysel görüşlerini almalı hem de sınıf içinde bir tartışma ortamı yaratarak etkinliği zenginleştirmeli, daha ilgi çekici ve daha eğlenceli hale getirmelidir. Ayrıca öğrencilerin hata yapmaktan korkmadığı, sorgulayan, soruna çözüm üreten ve kendilerini rahatça ifade edebilecekleri ortamların sağlanması da etkinlikten beklenilen başarının elde edilmesinde önemlidir.

\section{Konuşma Etkinliği}

Şüphesiz ki yabancı dil öğretiminin en önemli amaçlarından biri, öğrencilerin öğrendikleri dili akıcı ve anlaşılabilir bir şekilde konuşabilmelerdir. Günümüzde gelişen teknoloji, konuşma becerisinin geliştirilmesi için yeni olanaklar sunmaktadır. Bu olanaklardan yararlanmak bir yandan konuşma becerisinin önünde bir engel olarak duran öğretmen merkezli anlayışının terkedilmesine diğer yandan rol yapma, dramatizasyon, diyalog gibi etkinliklerin gerçekleştirilerek öğrencinin etkin olduğu, yaparak, yaşayarak ve eğlenerek öğrendiği göreve dayalı etkinliklerin gerçekleştirilmesine olanak sağlar. Nitekim 
dünyada ortalama 15 kişilik sınıflarda Almanca ve İngilizce olarak yürütülen dersleri kayıt altına alan DESEI'nin bir araştırmasında şu ilginç gerçekler ortaya çıkmıştır:

- Derslerde öğretmenlerin konuşma oranı \%70'tir.

- Derslerde öğrencilerin konuşma oranı \% 30'dur.

- Bir ders saatinde öğrencinin konuşma oranı ortalama bir dakikadır (Brünig-Saum 2011: 16-17'den akataran; Yücel 2016: 19).

Google'ın mobil uygulaması olan Google Çeviri ile konuşma becerisinin geliştirilmesine yönelik özellikle oyunlarla çeşitli diyaloglarda kullanılabilir. Otobüs durağı, pazar, mağaza, resepsiyon gibi çeşitli ortamlarda geçen diyaloglar örnek olarak alınabilir. Aşağıda bu araçların bir ders materyali olarak kullanıldığı bir etkinlik örneği görmektesiniz.

\begin{tabular}{|c|c|}
\hline Seviye & A2 \\
\hline Süre & 40 dakika \\
\hline Temel beceriler & Dinleme, konuşma \\
\hline Etkinlik türleri & Eğitsel oyun tekniği \\
\hline Amaç & $\begin{array}{l}\text { Öğrencilere sözlü olarak kendilerini ifade etme, anlama ve anlatma } \\
\text { becerilerini kazandırma }\end{array}$ \\
\hline Materyaller & $\begin{array}{l}\text { Otomatik çeviri aracı (Google Çeviri Mobil Uygulama), tablet, akıllı } \\
\text { telefon }\end{array}$ \\
\hline Süreç & $\begin{array}{l}\text { Birinci öğrenci yabancı dilde isteğini Google Çeviri aracına söyler, araç } \\
\text { konuşmayı çevirerek ikinci öğrenciye aktarır. İkinci öğrenci diğer dilde } \\
\text { Google çeviri aracına cevap verir. Araç konuşmayı yabancı dile } \\
\text { aktararak birinci öğrenciye iletir ve süreç bu şekilde devam eder. } \\
\text { Buradaki konuşmalar şahısların karakteristik özelliklerini yansıtacak } \\
\text { şekilde canlandırılır. Bu etkinlik farklı diyaloglar şeklinde diğer } \\
\text { öğrenciler arasında da devam eder. }\end{array}$ \\
\hline Metin & $\begin{array}{l}\text {-En yakın otobüs durağı nerede? } \\
\text {-Where is the nearest bus-stop? } \\
\text { - } 100 \text { meters ahead on the right. } \\
\text {-Sağda } 100 \text { metre ileride. }\end{array}$ \\
\hline Değerlendirme & $\begin{array}{l}\text { Öğrencilerin konuşmaları kontrol edilir. Yanlışları sınıf ortamında } \\
\text { düzeltilir. }\end{array}$ \\
\hline
\end{tabular}


Aşağıda Google Çeviri uygulamasının ekran görüntüsü yer almaktadır.

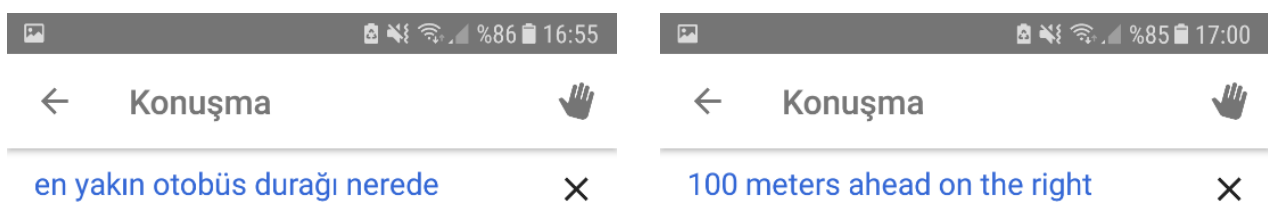

\section{Where is the nearest bus $\quad \rightarrow \quad$ Sağda 100 metre ileride stop?}

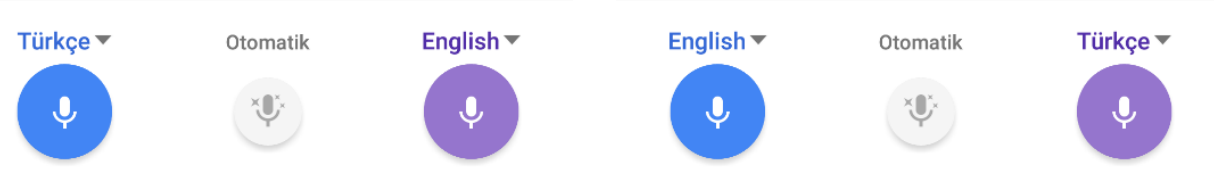

Resim 2 Google Çeviri uygulaması ekran görüntüleri

Bu etkinlikle öğrencilerin bir yandan pratik, anlama ve anlatma becerileri gelişirken diğer yandan da sözcükleri doğru telaffuz etme becerileri gelişmektedir. Yani hem konuşma hem de dinleme becerisinin geliştirilmesine katkı sağlamaktadır. Öğretmen etkinlik boyunca ikinci planda ve etkinliğin yönlendirilmesinden sorumludur. Fakat öğrencileri cesaretlendirmek için başlangıçta gönüllü öğrencilerden birisiyle bu etkinliği gerçekleştirebilir. Etkinliğin daha verimli olması için öğretmen önceden diyalog grupları oluşturabilir ve onlara senaryo metni verebilir veya senaryoyu öğrencilerin hazırlamasını isteyebilir.

\section{Dinleme Etkinliği}

Yabancı dil öğretimi-öğreniminde en önemli etkinliklerden biri olan dinleme etkinliği, birçok bilim insanına göre (Vandergrift 2004; O'Malley Chamot ve Kupper 1989) ifade edilen süreç ve aşamalar dikkate alındığında öğrenilmesi en zor beceri olarak düşünülmektedir (Melanlığlu 2015: 392). Dinleme becerisi kişisel bir yeti olmakla birlikte dinleme eğitimi niteliğinin ilişkili olduğu fiziksel nedenler, dinleme konusu, duygusal (dinleyici için özel olan bir konuyu hedef alan söylemler) ve psikolojik (düşünme ve anlamlandırma süreci) etkenler bulunmaktadır (Aytan-Güney, 2012'den aktaran; Tüfekçioğlu 2014). Bununla birlikte dinleme etkinlikleri dinleme öncesi, dinleme sırası ve dinleme sonrası olmak üzere üç farklı türde yapılmaktadır. Birbirini tamamlayıcı bu etkinler, bir bütün olarak dinleme etkinliğin daha verimli olmasını sağlamaktadır. 
Dinleme becerisine yönelik etkinlikler hazırlanırken öğrencilerin seviyeleri ve hazırbulunuşlukları gibi özellikler dikkate alınarak hazırlanır. Ayrıca bu etkinlikler çeşitli araç gereçlerle desteklenerek zenginleştirilebilir ve daha etkili hale getirilebilir. Günümüzde dinleme etkinliğinin gerçekleştirilmesi için teknolojinin sunduğu birçok yardımcı kaynak bulunmaktadır. Bilgisayar, tablet, cep telefonu, kasetçalar gibi araçlar, dinleme etkinliği için kullanılabilecek kaynaklardır. Otomatik çeviri araçları da sahip oldukları özellikler ile dinleme etkinliklerinde bir araç olarak kullanılabilirler. Örneğin dinleme metnindeki hataları bulma, karşılaştırma, özetleme, metni tartışma gibi etkinliklerde bu araçlardan yararlanılabilir.

Bununla birlikte dinleme etkinlikleri dinleme öncesi, dinleme sırası ve dinleme sonrası olmak üzere üç aşamada hazırlanmaktadır.

\begin{tabular}{|c|c|}
\hline Seviye & B1 \\
\hline Süre & 40 dakika \\
\hline Temel beceriler & Dinleme, yazma \\
\hline Etkinlik türleri & Ön bilgileri harekete geçirme, tartışma, yazma \\
\hline Amaç & $\begin{array}{l}\text { Öğrencilerin dinledikleri metni anlamaları ve metinle ilgili çıkarımda } \\
\text { bulunmaları ve metinle ilgili soru sorup cevap vermeleri sağlanır. }\end{array}$ \\
\hline Materyaller & Otomatik çeviri aracı (Google Çeviri Sitesi), bilgisayar, tablet \\
\hline Süreç & $\begin{array}{l}\text { Seçilen metin Google Çeviri 'ye girilir ve öğrencilere dinletilir. } \\
\text { Öğrenciler metni dinleyerek anlamaya çalışır. Gerekirse tekrar dinlenir. } \\
\text { Öğrenciler metinle ilgili düşüncelerini aktarır. Metinle ilgili soru-cevap } \\
\text { alıştırmaları yapılır. }\end{array}$ \\
\hline Metin & $\begin{array}{l}\text { Do you know these unusual but true facts about Facebook's founder, } \\
\text { Mark Zuckerberg? This genious young man has inspired every single } \\
\text { person on this planet and changed the whole world's communication. } \\
\text { When he was at the age of 12, he created a messaging program and his } \\
\text { father used it in his dental office. His parents hired a computer tutor to } \\
\text { work with the young Zuckerberg, but the tutor said that it was difficult } \\
\text { for him to teach Mark because he was a genious. Microsoft wanted } \\
\text { Mark to work with them when he was in high school after he created } \\
\text { "Synopse". It was a programme that used artificial intelligence to learn } \\
\text { user's music-listening habits. In 2010, Zuckerberg was "Time" } \\
\text { magazine's "Person of the Year". In December 2016, Zuckerberg was } \\
\text { ranked 10th on Forbes list of "The World's Most Powerful People". }\end{array}$ \\
\hline
\end{tabular}




\begin{tabular}{|c|c|}
\hline & $\begin{array}{l}\text { Zuckerberg was not a fan of "the Social Network", the movie about the } \\
\text { birth of Facebook because the details of the film were not true. In } 2014 \\
\text { Zuckerberg donated } \$ 25 \text { million to fight against the ebola virus } \\
\text { epidemic in West Africa. He has } 220.000 \text { Twitter followers but he's only } \\
\text { tweeted } 19 \text { times in four years. He owns a Hungarian sheepdog named } \\
\text { Beast who has a Facebook page with } 1,5 \text { million fans. Zuckerberg is } \\
\text { colour blind. He sees the colour blue best and he cannot see the colour } \\
\text { "red" and "green". That's why Facebook is mostly blue. He wears the } \\
\text { same gray Facebook T-shirt almost every day because he doesn't want } \\
\text { to lose time in front of the wardrobe in the morning as he is very busy. } \\
\text { He is a vegetarian and once he said he will only eat meat if he kills the } \\
\text { animal himself (Bulut ve diğerleri } 2017-2018: 127) \text {. }\end{array}$ \\
\hline Değerlendirme & $\begin{array}{l}\text { Öğrencilerin düzeltmeleri kontrol edilir. Yanlışları sınıf ortamında } \\
\text { düzeltilir. }\end{array}$ \\
\hline
\end{tabular}

Aşağıda Google çeviri uygulamasının etkinlikle ilgili ekran görüntüsü yer almaktadır.

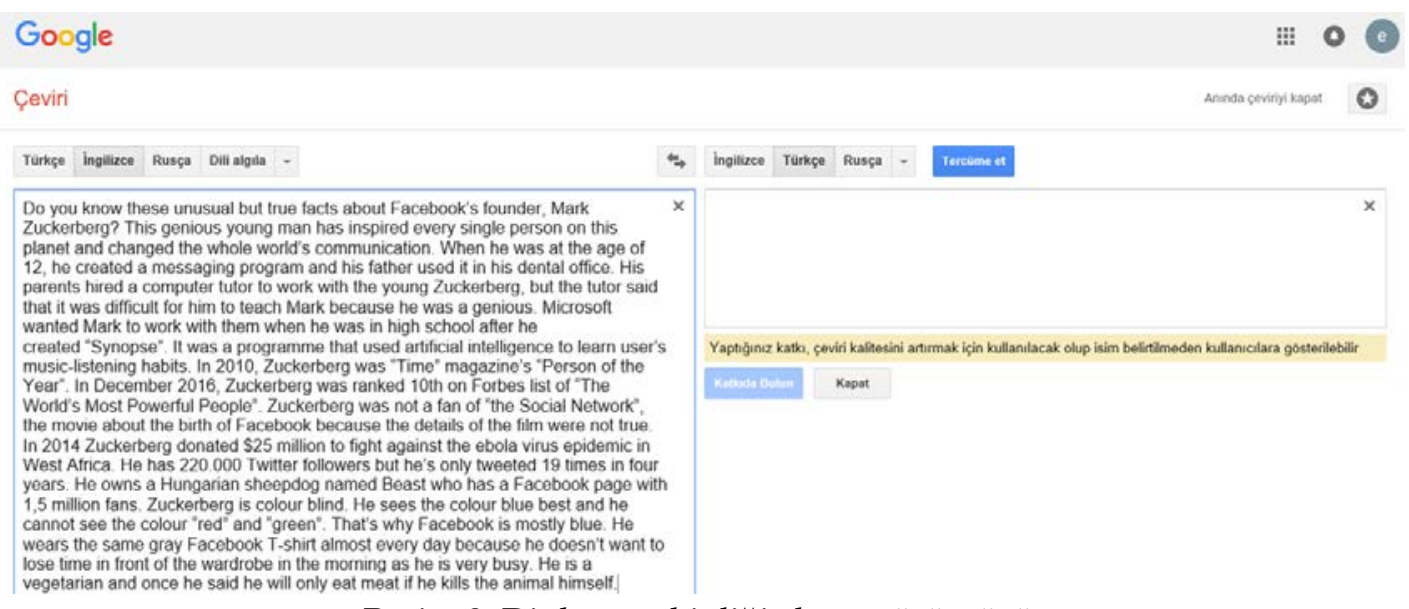

Resim 3. Dinleme etkinliği ekran görüntüsü

Dinleme öncesi etkinlikler için,

Hangi sosyal medya araçlarını kullanıyorsunuz?

Sosyal medya araçlarını kullanma amacınız nedir?

Facebook hakkında neler biliyorsunuz?

Dinleme anı etkinlileri için

Facebook kaç yılında kurulmuştur?

Facebook kim tarafından kurulmuştur?

Facebook ismini nereden alır?

Dinleme sonrası etkinliği için 
Sizce Facebook'un bu kadar hızlı gelişim göstermesinin sebebi nedir?

Facebook'un yaygın kullanılmasının sebebi ne olabilir? Tartışınız.

Facebook'ta değişiklik yapmak isteseydiniz bu ne olurdu? Niçin? Açılayınız! gibi sorular sorulabilir.

\section{Okuma Etkinliği}

Öğrencinin okuduğunu anlamasına yönelik olan bu etkinler için çeşitli teknikler kullanılmaktadır. Bunlardan verim alınabilmesi için öncelikle öğrencinin motivasyonu, okuma öğrenme ortamı, metin türü ve öğrencinin metindeki konuya ilişkin ön bilgileri, metnin öğrencinin dil düzeyine uygunluğu gibi değişkenler önemli bir yer tutar. Yabancı dil öğretiminde kullanılacak metinlerin özellikleri ise şu şekilde sıralanabilir

- Metinler belirli dil yapılarını ve sözcükleri öğretmelidir.

- Metnin dil düzeyi, öğrencinin düzeyinin biraz üstünde olmalıdır.

- Metinler, temel okuma stratejilerini desteklemelidir.

- Metinlerin içeriği öğrencilerin ilgilerini çekmelidir.

- Metinler, öğrenciler için uygun dil düzeyinde ve özgün olmalıdır.

- Metnin uzunluğu başlangıç düzeyindeki öğrenciyi yıldıracak nitelikte olmamalıdır.

- Metinler, farklı sınıf içi etkinliklere dönüştürülerek kullanılmaya uygun olmalıdır. (Wallace 1992: 71; Haley-Austin 2004: 159'dan aktaran; Bölükbaş 2015: 925).

Okuma becerisinin gelişmesine yönelik etkinlerde dinleme etkinliklerine de yer verilmesi okuma becerisinin geliştirilmesine katkı sağlayacaktır. Nitekim son yıllarda ortaya çıan yaklaşım dinleme, konuşma, okuma ve yazma becerilerinden herhangi birinin gelişmesinin diğerlerinin gelişiminde de katkı sağlayacağı yönündedir. Örneğin, dinleme ve okuma, bilgi dışarıdan geldiği için "alıı beceriler" olarak nitelendirilmektedir. Öte yandan, konuşma ve yazma, bilgi dışarıya yollandığı için "verici beceriler" olarak nitelendirilmektedir ve bu beceriler birbirini desteklemektedir (Yangin 1998). Aşağıda bu yaklaşımın dikkate alındığı bir okuma etkinliği örneği yer almaktadır.

\begin{tabular}{|c|c|}
\hline Seviye & B1 \\
\hline Süre & 40 dakika \\
\hline Temel beceriler & Dinleme, okuma \\
\hline Etkinlik türleri & Seçilen metni dinleme ve okuma. \\
\hline Amaç & $\begin{array}{l}\text { Öğrencilerin dinledikleri metni anlamaları ve metinle ilgili çıkarımda } \\
\text { bulunmaları ve metinle ilgili sorulan sorulara cevap vermeleri sağlanır. }\end{array}$ \\
\hline Materyaller & Otomatik çeviri aracı (Google Çeviri Sitesi), bilgisayar, tablet, ders kitabı \\
\hline Süreç & $\begin{array}{l}\text { Seçilen metin Google Çeviri'ye girilir ve öğrencilere dinletilir. } \\
\text { Öğrenciler metni dinleyerek telaffuz, vurgu ve tonlama gibi özelliklere } \\
\text { dikkat eder ve daha sonra kendileri okur. Okuduktan sonra metni } \\
\text { anlayıp anlamadığına yönelik alıştırmalar yapılır. }\end{array}$ \\
\hline Metin & $\begin{array}{l}\text { Millions of people around the world use mobile phones to keep in touch } \\
\text { with their friends and family, and there is an } 80 \% \text { chance you've got a }\end{array}$ \\
\hline
\end{tabular}




\begin{tabular}{|c|c|}
\hline & $\begin{array}{l}\text { mobile phone in your pocket or bag. How does a mobile phone network } \\
\text { work? } \\
\text { A mobile phone is actually a sophisticated radio. It uses radio waves to } \\
\text { communicate, like a walkie-talkie. Only one person can talk with a } \\
\text { walkie-talkie because it uses one channel and one frequency. The mobile } \\
\text { phone uses two frequencies, one for talking and one for listening, and } \\
\text { two people can talk at the same time. } \\
\text { When your mobile phone is on, the phone communicates to a base } \\
\text { station. There are usually hundreds of base stations in cities all over the } \\
\text { world. Sometimes telephone companies disguise their base stations, so } \\
\text { you don't notice them. Each base station is at the centre of a cell. All the } \\
\text { calls and messages in that area go to the cell's base station. A special } \\
\text { base station controller transmits the call. Controllers can take a certain } \\
\text { number of calls at the same time, so if a lot of people call, some of them } \\
\text { may not be able to get through. This doesn't happen very often } \\
\text { (Kandilci 2016: } 42 \text { ). }\end{array}$ \\
\hline Değerlendirme & $\begin{array}{l}\text { Öğrencilerin okumaları kontrol edilir. Metinle ilgili sorulan sorulara } \\
\text { verilen cevaplar gözden geçirilir ve gerekli düzeltmeler yapılır. }\end{array}$ \\
\hline
\end{tabular}

Aşağıda Google Çeviri uygulamasının bu etkinlikle ilgili ekran görüntüsünü görmektesiniz.

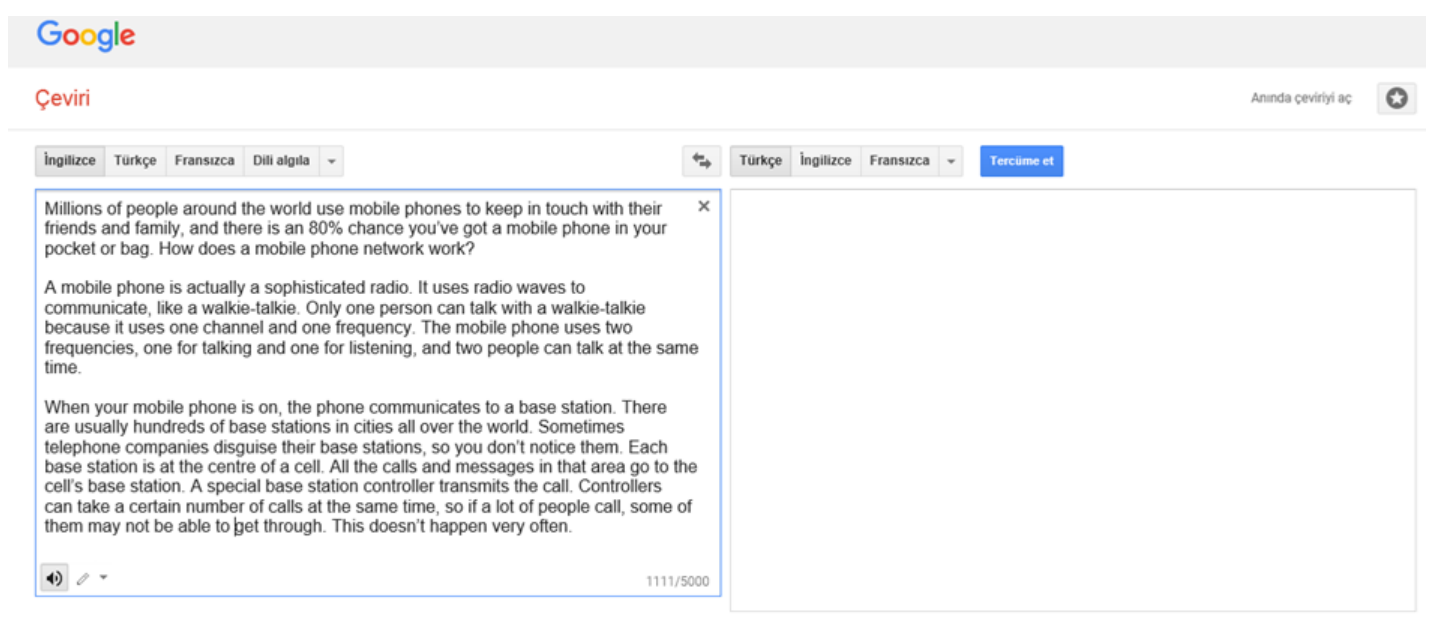

Resim 4. Okuma etkinliği ekran görüntüsü

Öğrenci metni dinledikten sonra metinle ilgili olarak doğru yanlış, sözcük eşleştirme veya boşluk doldurma gibi alıştırmalara yer verilerek öğrencinin metni anlayıp anlamadığ 
değerlendirilir. Otomatik çeviri araçları vurgu ve tonlama gibi parçalarüstü sesbirimleri açısından henüz istenilen düzeyde olmasa da özellikle öğrencilerin sözcükleri doğru telaffuz etmelerine katkılar sunabilir. Öğretmen okunacak metni önceden gözden geçirerek hatalı telaffuz veya başka türlü olumsuzlukların ortaya çıkmasını engelleyebilir.

\section{YÖNTEM}

Araştırmada durum çalışması kullanılmıştır. “Durum çalışmasında, bir veya birkaç duruma ilişkin etkenler bütüncül bir yaklaşımla araştırılır ve ilgili durumu nasıl etkiledikleri ve ilgili durumdan nasıl etkilendikleri üzerine derinlemesine araştırma yapılır" (YıldırımBahçekapılı E. vd. 2011).

\section{Çalışma Grubu}

Çalışmanın evrenini 2017-2018 sonbahar döneminde Marmara Üniversitesi Fransızca Mütercim Tercümanlık bölümünde öğrenim gören ve İngilizce dersini alan 20 öğrenci oluşturmaktadır.

\section{Veri Toplama Aracı}

Araştırma için örnek ders etkinlikleri hazırlanmış ve sınıf ortamında gerçekleştirilmiştir. Etkinlik sırasında gözlem tekniğinden yararlanılmış, etkinlik sonrasında ise alan yazın taranarak ve uzman görüşü alınarak hazırlanan anket formu kullanılmıştır.

\section{Verilerin Analizi}

Elde edilen verilerin analizinde Betimsel İstatistik Tekniği kullanılmıştır. "Betimsel istatistik, bir değişken içerisinde her bir değerin ya da değer kümesinin kaç kez tekrar ettiği, değerlerin merkez olarak seçilen bir nokta etrafında nasıl bir dağılım gösterdiği, orta noktaya ya da birbirlerine göreceli olarak nasıl bir uzaklıkta oldukları gibi özet bilgileri kapsamaktadır" (Akbulut 2012: 168). Maddelerin analizinde ise İçerik Analizinden yararlanılmıştır.

\section{BULGULAR VE TARTIŞMA}

Ankete verilen cevaplara baktığımızda etkinliğe katılan öğrencilerin $18^{\prime}$ i otomatik çeviri araçlarını daha önce öğrenim amaçlı kullandığını belirtirken 2 öğrenci kullanmadığını belirtmiştir. Çalışmanın diğer verileri tablolar şeklinde aşağıda sunulmuştur.

Tablo 1. Otomatik çeviri araçlarının kullanım amacı Cevaplar

Sözcüklerin anlamına bakıyorum

$14 \quad 78$

Sözcüklerin telaffuzunu dinliyorum

1

5.5

Çeviri amaçlı kullanıyorum

1

5.5

Sözcük ve metinlerle ilgili hataları tespit etmek

için kullanıyorum

Yukarıdaki tabloya baktığımızda Otomatik Çeviri araçlarını daha önce öğrenim amaçlı kullandığını belirten öğrencilerin büyük bir oranda bu araçları birer sözlük olarak kullandıkları görülmektedir. Kalın ve ağır basılı sözlükleri taşımanın zahmetli olmasından, 
sözcüklere ulaşmanın kolay olmasından ayrıca sözcüklerin telaffuzlarının dinlenebilir olmasından dolayı öğrencilerin bu araçları bir sözlük yerine kullandıklarını söyleyebiliriz. Nitekim bu amaçla Aslan (2016: 4) tarafından yapılan bir çalışmada öğrencilerin bu yönde görüş bildirdikleri ortaya çıkmıştır. Öğrencilerin sözcüklerin anlamına bakmak dışında telaffuz, çeviri ve hata tespiti gibi amaçlarla da bu araçları kullandıkları görülmektedir.

Tablo 2. Otomatik Çeviri Araçlarının Eğitsel Yönü

\begin{tabular}{|c|c|c|c|c|c|c|}
\hline \multirow[t]{2}{*}{ Sorular } & \multicolumn{2}{|c|}{ Evet } & \multicolumn{2}{|c|}{ Hayır } & \multicolumn{2}{|c|}{ Kismen } \\
\hline & $\mathrm{f}$ & $\%$ & f & $\%$ & $\mathrm{f}$ & $\%$ \\
\hline $\begin{array}{l}\text { Otomatik çeviri araçları dil öğretiminde etkili } \\
\text { bir ders aracı olabilir }\end{array}$ & 12 & 60 & - & - & 8 & 40 \\
\hline $\begin{array}{l}\text { Otomatik çeviri araçları bireysel öğrenme } \\
\text { gereksinimlerini karşılayabilir }\end{array}$ & 6 & 30 & 3 & 15 & 11 & 55 \\
\hline $\begin{array}{l}\text { Otomatik çeviri araçları ders motivasyonunu } \\
\text { arttırabilir }\end{array}$ & 10 & 50 & 5 & 25 & 5 & 25 \\
\hline $\begin{array}{l}\text { Otomatik çeviri araçları ile yapılan etkinlik } \\
\text { eğlenceli olabilir }\end{array}$ & 6 & 30 & 2 & 10 & 12 & 60 \\
\hline
\end{tabular}

Otomatik çeviri araçları dil öğretiminde etkili bir ders aracı olabilir mi sorusuna öğrencilerin olumlu yaklaştıkları görülmektedir. Nitekim ses tanıma ve algılama, metinlerin yazılı, sözlü veya fotoğraflarının çekilerek sisteme girilebilmesi ve metinlerin dinlenebilmesi ayrıca birer sözlük olarak kullanılabilme özellikleri başta olmak üzere diğer özellikleri ile birlikte bu araçların etkili birer ders materyali olabileceği değerlendirilmektedir. Bununla birlikte bu araçların etkili birer ders aracı olabilmelerinin öğretmen, öğrenci, ortam gibi başka unsurlara da bağlı olduğunu aklımızdan çıkarmamız gerekir.

Otomatik çeviri araçlarının bireysel öğrenme ihtiyaçlarını karşılayabileceklerini düşünen öğrencilerin sayısı dikkat çekicidir. Şüphesiz ki öğrencilerin beklentileri, öğrenme tarzları, öğrenme hızları, ilgileri ve yetenekleri birbirinden farklıdır. Bu farklılıkların dikkate alındığı bireyselleştirilmiş öğretimde, öğrenci öğrenme sorumluluğunu üstlenerek ne öğreneceğine, nasıl öğreneceğine, ne zaman, hangi hızla öğreneceğine kendisi karar verir. $\mathrm{Bu}$ araçlar bireyselleştirilmiş öğretime uygun özelliklere sahip olmasından dolayı uygun yöntem ve tekniklerle bu amaçlar doğrultusunda kullanılabilir.

$\mathrm{Bu}$ araçların ders motivasyonunu artırdığını söyleyebiliriz. Yapılan çalışmada otomatik çeviri araçlarının öğrencilerin dikkatini çektiğini ve onlarda ilgi uyandırdığ 1 görülmektedir. İlgi çeken araçların öğrencinin derse motive olmasına ve etkili öğrenmeler gerçekleştirilmesine katkı sağladığı eğitim bilimciler tarafından kabul edilen bir gerçektir. Bu araçların güncellenebilir olabilmeleri yani yeni özelliklerin eklenmesi ve içeriğinin sürekli geliştirilebilmesi hem öğrencide merak uyandırarak motivasyon artırıcı bir unsur olarak değerlendirilebilir hem de durağan olmayan etkin bir ders aracı olarak görülebilir.

Otomatik çeviri araçları ile yapılan etkinlikleri eğlenceli bulan öğrencilerin sayısı yine büyük çoğunluktadır. Özellikle akıllı telefonlar ve tabletler için sunulan Google Çeviri 
uygulaması eğlenceli etkinlikler için fırsatlar sunmaktadır. Bu fırsatlardan yararlanılarak eğlenceli ders ortamları yaratılabilir. Eğlenceli ders ortamları, başarısızlık korkusu, stres, kaygı gibi yabancı dil öğretiminde sık karşılaşılan olumsuzlukların ortaya çıkmasını engeller ve öğrencilerin öğrendikleri dile karşı olumlu tutum geliştirmelerine yardımcı olur.

Tablo 3. Otomatik çeviri araçlarının sınırlılıkları

\section{Cevaplar}

Sözcüklerin anlamını doğru vermemektedir

Kullanılan sesler doğal insan sesi değildir

Çeviri beklentileri karşılamamaktadır

Bu araçların dil öğretiminde nasıl kullanılacağına dair

yeterli çalışma yoktur f $\quad \%$

3

6

10

50

15

30

1

5

Otomatik çeviri araçlarının bazı sınırlılıkları da mevcuttur. Öğrencilerin yarısı çeviri kalitesinin istenilen düzeyde olmadığını belirtmektedir. Çeviri kalitesini dikkate alarak öğretmenler, metin tercihi yaparken seçici davranmalı ve etkinliklerde kullanılacak metinleri önceden sisteme girerek kontrol etmeleri önem arz etmektedir. Zira ortaya çıkabilecek hataların önüne geçilmesi ve beklenmedik durumların yaşanmaması için bu gereklidir. Bunun yanında kullanılan seslerin doğal insan sesi olmaması bir öğretim materyali olarak bu araçların zayıf yönü olarak değerlendirilmektedir. Ayrıca deyim, atasözü ve kalıp söz gibi söz varlıklarının karşılıklarının bulunmasında bu araçlar sözlük özelliklerini zaman zaman yerine getiremeyebilirler. Öğretmenler, bu durumu dikkate alarak etkinlikleri hazırlamalılar. Ayrıca bu araçların birer ders materyali olarak kullanıldığı yeni çalışmalara da ihtiyaç duyulduğu düşünülmektedir.

\section{SONUÇ}

Günümüzde farklı amaçlar için tasarlanmış fakat eğitsel yönü bulunmasından dolayı pek araç birer ders materyali olarak kullanılabilmektedir. Televizyondan videoya, radyodan telefona kadar farklı türde araçlardan yabancı dil öğretiminde yararlanılmaktadır. Bu araçların yardımcı birer ders materyali olarak etkin bir şekilde kullanılması, ders etkinliklerinden verim elde edilmesi ve istenilen başarıya ulaşılması şüphesiz ki yalnızca bu araçların sahip oldukları özelliklere bağlı değildir. Öğretmenin tutumu ve becerisi, öğrencinin yaklaşımı, ortamın sunduğu imkânlar gibi etkenler başarının ortaya çıkışında önem arz etmektedir. Bununla birlikte hem Google Çeviri sitesinin hem de uygulamasının ücretsiz ve kullanımının kolay olması bu araçların en önemli avantajlarından olduklarını söylemek gerekir. Günümüzde hemen hemen bütün öğretmenlerde birer akıllı telefon, tablet veya bilgisayar bulunmaktadır. Öğretmenler otomatik çeviri araçlarını kullanarak birkaç dokunuşla ders etkinlikleri hazırlayabilir ve dersleri daha eğlenceli hale getirerek öğrenme yaşantılarını zenginleştirebilirler. Zira Bilginin klasik yöntemlerin dışına çıkılarak farklı şekillerde aktarılması özellikle yeni ve ilgi çekici araçlarla sunulması dersleri tekdüzelikten kurtararak eğlenceli hale getireceği muhakkaktır. Eğlenceli etkinlikler, öğrencilerin merak ve ilgilerini canlı tutarak motivasyonlarını artıracak ve böylelikle etkili öğrenmeler gerçekleştirilmesine katkı sağlayacaktır. 


\section{SUMMARY}

Automatic translation, also called machine translation and computer translation, is the automatic translation of texts from one language to another, with computers and mobile devices without human intervention. In the last fifty years, developments in the field of technology have enabled the development of tools for better translation, especially in the western languages. Since a few years, we have seen applications developed that make better translations between structurally different languages such as Turkish, Korean and Chinese. Despite this, however, it is not yet possible to translate high quality by machine translation. The most important reason for this is that they cannot accurately reflect the subtleties of the language.

However, the facilities provided by these tools are not limited to translation. These tools, which also function as a dictionary, can be used in speaking, listening, reading and writing activities in foreign language teaching. For example, since words can be entered both systematically and verbally, the student can learn both the meaning of the word and its use in the sentence, while listening to the pronunciation of the words and evaluating their own pronunciations. In addition, it will benefit from automatic translation tools for teaching vocabulary such as idioms, proverbs, and phrases. In addition, these tools can be used to teach structural similarities and differences between languages. To provide access to these opportunities by mobile applications without space and time constraints is one of the most important feature of these tools.

However, it is not yet clear how effective and efficient these facilities provided by automatic translation tools are used by students. In this study, on the one hand, it is tried to be determined if students are benefiting from these tools while learning foreign languages, how efficiently they use them, what exercises they use these tools, what are the shortcomings and limitations, on the other hand, the current situation is tried to be revealed by making sample activities with these tools and so that it is sought to find ways of using these tools effectively and efficiently as teaching materials.

Four sample events were prepared for this purpose and they were realized in the English course of French Translation and Interpretation Department of Marmara University in autumn 2017-2018. In addition, a questionnaire consisting of closed and open ended questions was prepared and administered after the event. Descriptive Statistical Technique was used in the analysis of the obtained data and Content Analysis was used in the analysis of open ended questions. 


\section{KAYNAKÇA}

Akbulut, Yavuz (2012). "Veri Çözümleme Teknikleri”. Sosyal Bilimlerde Araștırma Yöntemleri. ed. Ali Güngör. Eskişehir: Anadolu Üniversitesi Açıöğretim Fakültesi Yay. 162-195.

Aktaş, Tahsin (2005). "Yabancı Dil Öğretiminde İletişimsel Yeti". Journal of Language and Linguistic Studies 1 (1): 89100. http://dergipark.ulakbim.gov.tr/jlls/article/view/5000084165 [10.12.2017].

Aslan, Erdinç (2016). "A study on the use of mobile dictionaries in vocabulary teaching". Journal of Language and Linguistic Studies 12 (1): 18. http://www.jlls.org/index.php/jlls/article/view/463 [01.01.2018].

Bölükbaş, Fatma (2015). "Yabancı Dil Olarak Türkçe Öğretiminde Okuma Metinlerinin Dil Düzeylerine Göre Sadeleştirilmesi". International Journal of Languages' Education and Teaching UDES 2015: 924-935.

Bulut, Ebru-Ertopçu, Funda Baydar vd. (2017-2018). Secondary Educatıon Teenwise Student's Book. Milli Eğitim Bakanlığı Ders Kitabı.

Callı, Ahmet (2016). Makine Çevirileri. http://www.estr.com/index.php/tr/makine-cevirileri/ [14.12.2017].

Chéragui, Mohamed Amine (2012). "Theoretical Overview of Machine translation". Web and Information, 4th International Conference on Web and Information Technologies ICWIT 2012. April 29-30 2012. Sidi Bel-Abbes, Algeria. 160-169.

Gil, José Ramón Biau-Pym, Anthony (2006). Technology and Translation. A Pedagogical Overview. In Translation Technology and Its Teaching (with Much Mention of Localization). Tarragona: Intercultural Studies Group.

Günday, Rıfat (2015). Yabancı Dil Öğretiminde Yaklaşımlar, Yöntemler, Teknikler ve Multimedya Araç ve Materyaller. Ankara: Favori Yay.

Kandilci, Esra (2016-2017). Middle Schoolmoonlight English Course Grade 8 Student's Book. Milli Eğitim Bakanlı̆̆ı Ders Kitabı. Anakar: Tutku Yay.

Kuşçu, Ertan (2017). "Yabancı Dil Öğretimi/Öğreniminde Görsel Ve İşitsel Araçları Kullanmanın Önemi". The Journal of Academic Social Science 5 (43): 213-224.

Melanlığlu, Deniz (2015). "Yabancı Öğreniciler İçin Dinleme Becerisine Yönelik Üstbilişsel Dereceli Puanlama Anahtarı A Metacognitıve Rubric For Turkısh Learners' Listening Skills". Erzincan Üniversitesi Sosyal Bilimler Enstitüsü Dergisi (ERZSOSDER) ÖS-II: 391404.

Mihrabi, Hüseyin (2006). "Ingilizce-Türkçe (Machine Translation$M T)^{\prime \prime}$. http://www.sametran.com/index.php?content=ingilizceturkce [08.12.2017].

Novak, Matt (2015). "Google tercüme Soğuk Savaş ürünü mü?". http://www.bbc.com/turkce/ozeldosyalar/2015/01/150108 vert fut google tercu me [14.11.2017].

Takıl, Nazife Burcu (2016). "Yabancı Dil Olarak Türkçe Öğretiminde Yazma Becerisini Geliştirmeye Yönelik Bir Eylem Araştırması: Döngüsel Yazma Etkinliği". Türkiye Sosyal Araștırmalar Dergisi 20 (1): 299-312.

Tecer, Meral (1980). Ingilizce Meslek Bilgisi. Ankara: Yarg1.. Yay. 2. bs.

Tüfekçioğlu, Burak (2014). "Yabancı Dil Olarak Türkçe Öğretiminde Dinleme Etkinlikleri İle Sözcük Öğretimi Üzerine Bir Araştırma: Çukurova TÖMER Örneği". E-Dil (2): 35-51.

Yaguello, Marina (1944). Hayali Diller: Söylenceler, Ütopyalar, Fantazmalar, Kuruntular ve Dilsel Kurgular, çev. Necmettin Kamil Sevil. İstanbul: Yapı Kredi Yay.

Yalın, Halil İbrahim (2010). Öğretim Teknolojileri ve Materyal Geliştirme. Ankara: Nobel Yayın Dağıtım. 22. bs.

Yangın, Banu (1998). Dinlediğini Anlama Becerisini Geliştirmede Elves Yönteminin Etkisi. Doktora Tezi. Ankara: Hacettepe Ü.

Yet Çeviri (2016). Bilgisayar Destekli Tercüme Araçları. http://www.yet.com.tr/bilgisayardestekliceviri-araclari/ [04.11.2016].

Yıldırım, Gürkan-Bahçekapılı, Ekrem vd. (2011). Eğitimde Nitel Araştırma Yöntemleri: Durum Çalışması (Case Study). Erzurum: Atatürk Ü.

Yücel, Erdinç (2016). "2. Yabancı Dil Öğretiminde Konuşma Becerisi”. Yabancı Dil Öğretimine Genel Bir Bakış. ed. Erdinç Yücel vd. İstanbul: Çizgi Kitabevi Yay. 